\title{
PENGARUH UKURAN PERUSAHAAN, PROFITABILITAS, LEVERAGE, EFISIENSI BIAYA, DAN UMUR PERUSAHAAN TERHADAP ISLAMIC SOCIAL REPORTING (ISR) PADA PERBANKAN SYARIAH DI INDONESIA
}

\author{
Ari Kristin Prasetyoningrum \\ ${ }^{1}$ Universitas Islam Negeri Walisongo Semarang \\ $\bowtie$ ari.kristin@gmail.com
}

\begin{abstract}
Islamic Social Reporting (ISR) is one of the indices of social responsibility disclosure whose indicators refer to Islamic ethical principles. Islamic banking operates according to Islamic principles, so ISR disclosures in Islamic banking should be within the corridor of Islamic values. This study aims to identify the factors that affect the disclosure level of Islamic Social Reporting (ISR) in sharia banking in Indonesia. Factors studied in this study are company size, profitability, leverage, efficiency and age of the company. The result of the research shows that the factor of financial factor in this research is firm size (SIZE), Profitability (ROA), Leverage (DER) and Cost Efficiency (BOPO) proved not significant influence to ISR, while Company Age factor (AGE) is statistically proven significant effect on the ISR.
\end{abstract}

Keywords: capital, efficiency, profitability

\section{LATAR BELAKANG}

Tanggung jawab sosial perusahaan (corporate social responsibility) merupakan salah satu dari beberapa tanggung jawab perusahaan kepada pemangku kepentingan (stakeholders). Praktek pengungkapan Corporate Social Responsibility (CSR) memainkan peranan penting bagi perusahaan karena perusahaan hidup di lingkungan masyarakat dan aktivitasnya memiliki dampak sosial dan lingkungan. Dengan demikian pengungkapan tanggung jawab sosial merupakan alat manajerial yang digunakan perusahaan untuk menghindari konflik sosial dan lingkungan (Mulia, 2009). Pelaksanaan CSR pada dasarnya berorientasi dari dalam ke luar, artinya perusahaan harus dikelola dengan baik agar tidak menimbulkan dampak negatif bagi lingkungannya (Solihin, 2011).

CSR tidak hanya terdapat pada ekonomi konvensional, tetapi berkembang juga pada ekonomi syariah. Haniffa (2002) dalam Khoirudin (2013) menyatakan bahwa selama ini pengukuran CSR disclosure pada perbankan syariah masih mengacu pada Global Reporting Initiative Index (GRI) yang hanya mengacu pada pelaporan sosial yang dilakukan oleh lembaga konvensional sehingga ia mengemukakan kerangka konseptual Islamic Social Reporting. Terkait dengan adanya kebutuhan mengenai pengungkapan tanggung jawab sosial di perbankan syariah, saat ini, marak diperbincangkan mengenai Islamic Social Reporting Index (selanjutnya disebut indeks ISR).

Othman et al. (2009) mengembangkan indeks pengungkapan yang relevan dengan hal-hal yang telah disebutkan sebelumnya pada Islamic Social Reporting (ISR) Index. ISR pertama kali dikemukakan oleh Haniffa (2002) lalu dikembangkan secara 
lebih ekstensif oleh Othman et al. (2009) di Malaysia. Haniffa (2002) mengungkapkan bahwa adanya keterbatasan dalam pelaporan sosial konvensional sehingga ia mengemukakan kerangka konseptual Islamic Social Reporting berdasarkan ketentuan syariah yang tidak hanya membantu pengambilan keputusan bagi pihak muslim melainkan juga untuk membantu perusahaan dalam melakukan pemenuhan kewajibannya terhadap Allah Subhanaahu wa Ta"ala dan masyarakat.

Berdasarkan hasil penelitian sebelumnya yang dilakukan oleh Othman et al. (2009) menentukan bahwa ukuran perusahaan, profitabilitas, dan ukuran dewan direksi muslim secara signifikan mempengaruhi tingkat pengungkapan ISR, sedangkan tipe industri bukanlah faktor penting yang mempengaruhi ISR secara signifikan. Oleh karena itu, penulis berkeinginan untuk mengembangkan penelitian sebelumnya yang dilakukan oleh Othman et al. (2009) dengan menggunakan ISR sebagai indeks pengungkapan tanggung jawab sosial terhadap Perbankan Syariah di Indonesia.

\section{TEORI DAN METODE}

\subsection{Islamic Social Reporting (ISR)}

Islamic Social Reporting merupakan bentuk tanggung jawab perusahaan terhadap lingkunganya bagi kepedulian sosial maupun tanggung jawab lingkungan dengan tidak mengabaikan kemampuan daripada perusahaan yang sesuai dengan prinsip Islam. ${ }^{i}$ Salah satu cara utuk menilai pelaporan tanggung jawab sosial perusahaan secara syariah yaitu dengan menggunakan indeks Islamic Social Reporting (ISR). Haniffa (2002), ISR adalah perpanjangan pelaporan sosial yang meliputi tidak hanya harapan dewan pengurus atas pandangan masyarakat terhadap peran perasaan dalam ekonomi tetapi juga pemenuhan perspektif spiritual untuk pengguna laporan yang muslim. Islamic Social Reporting memiliki dua tujuan utama, yang pertama sebagai akuntabilitas kepada Allah SWT dan komunitas dan yang kedua yaitu untuk meningkatkan transparansi kegiatan bisnis dengan cara memberikan informasi yang relevan dan sesuai dengan kebutuhan spiritual para pembuat keputusan muslim. Selain itu indeks ISR juga menekankan pada keadilan sosial terkait pelaporan mengenai lingkungan, kepentingan minoritas dan karyawan.

Corporate Social Responsibility (CSR) tidak hanya terdapat pada ekonomi konvensional tetapi berkembang juga dalam ekonomi Islam dengan salah satu alat pengukurnya Islamic Social Reporting (ISR) Index yang pertama kali diperkenalkan oleh Haniffa pada tahun 2002 yang kemudian dikembangkan oleh Othman et.al., pada tahun 2009. Pada saat itu Haniffa melihat keterbatasan pada kerangka pelaporan sosial yang dilakukan oleh lembaga konvensional sehingga ia mengemukakan kerangka konseptual Islamic Social Reporting (ISR) berdasarkan ketentuan syariah yang tidak hanya membantu pengambilan keputusan bagi pihak muslim melainkan juga untuk membantu perusahaan dalam melakukan pemenuhan kewajiban terhadap Allah SWT, dan masyarakat.

Konsepsi tanggung jawab dalam Islam mempunyai sifat berlapis ganda dan terfokus baik pada tingkat mikro (individual) maupun tingkat makro (organisasi dan sosial), yang kedua-duanya harus dilakukan secara bersama-sama. Menurut Sayyid kutub Islam mempunyai prinsip pertanggung jawaban yang seimbang dalam segala bentuk dan ruang lingkupnya. Antara jiwa dan raga, antara person dan keluarga, individu dan sosial antara suatu masyarakat dengan masyarakat lainya. 


\section{Ukuran Perusahaan}

Semakin besar ukuran perusahaan biasanya informasi yang tersedia untuk investor dalam pengambilan keputusan terkait dengan investasi dalam perusahaan tersebut semakin banyak. Penelitian terdahulu telah membuktikan bahwa tingkat pengungkapan perusahaan akan semakin meningkat seiring dengan semakin besarnya ukuran perusahaan. Ukuran perusahaan tidak hanya berpengaruh signifikan terhadap tingkat pengungkapan sukarela tetapi juga terhadap tingkat pengungkapan wajib (Ayu, 2010). Menurut Hossain et al (2006), ukuran perusahaan dapat diukur dengan menggunakan jumlah karyawan, nilai total asset dan volume penjualan, namun ketiga proxy tersebut sangat berkorelasi tinggi antara satu dengan yang lain. Penelitian terkait dengan ukuran perusahaan dan ISR pernah dilakukan oleh Otman et al (2009) dan Ayu (2010). Penelitian Otman (2009) selaras dengan penelitian-penelitian sebelumnya yang mengindikasikan bahwa ukuran perusahaan berpengaruh positif dan signifikan terhadap pengungkapan ISR. Sedangkan penelitian Ayu (2010) mengindikasikan bahwa ukuran perusahaan memiliki pengaruh negative yang signifikan terhadap tingkat pengungkapan ISR.

\section{Profitabilitas}

Profitabilitas menunjukkan kemampuan perusahaan untuk meghasilkan laba selama periode tertentu. Profitabilitas suatu perusahaan diukur dengan kesuksesan perusahaan dan kemampuan menggunakan aktivanya secara produktif, dengan demikian profitabilitas suatu perusahaan dapat diketahui dengan memperbandingkan antara laba yang diperoleh dalam suatu periode dengan jumlah aktiva atau jumlah modal perusahaan tersebut.

Ratio profitabilitas adalah ratio-ratio yang dapat digunakan untuk menilai kemampuan perusahaan untuk memperoleh keuntungan. Perusahaan yang berada pada posisi menguntungkan akan cenderung melakukan pengungkapan informasi yang lebih luas dalam laporan tahunannya. Sebaliknya, jika profit perusahaan menurun maka manajer akan cenderung mengurangi informasi yang diungkapkan dengan tujuan untuk menyembunyikan alasan-alasan mengapa profit perusahaan mengalami penurunan.

Secara spesifik terhadap ISR, penelitian Naser (1998), Chau dan Gray (2002), Akhtaruddin (2005), Haniffa dan Cooke (2005), Omar dan Simon (2011) membuktikan bahwa profitabilitas memiliki pengaruh positif signifikan terhadap tingkat pengungkapan wajib maupun sukarela. Hasil tersebut bertolak belakang dengan hasil penelitian Hossain dan Hammami (2009) dan Adelopo (2011) yang menemukan bahwa profitabilitas memiliki pengaruh negatif signifikan terhadap tingkat pengungkapan wajib dan sukarela. Selain itu, Ho dan Wong (2001), Hossain et al., (2006), Aljifri (2008), Liu dan Anbumozhi (2008), Chau dan Gray (2010), Zourarakis (n.d.) menemukan bahwa profitabilitas tidak memiliki pengaruh terhadap tingkat pengungkapan laporan tahunan perusahaan. Hasil ini selaras dengan hasil pemaparan Haniffa (2002) yang menyatakan bahwa dalam pandangan Islam perusahaan yang memiliki niat untuk melakukan pengungkapan penuh tidak akan mempertimbangkan apakah perusahaan tersebut untung atau rugi.

\section{Leverage}

Leverage timbul karena perusahaan dalam operasinya menggunakan aktiva dan sumber dana yang menimbulkan beban tetap bagi perusahaan. Penggunaan aktiva yang menimbulkan beban tetap disebut dengan operating leverage, sedangkan 
penggunaan dana dengan beban tetap disebut financial leverage. Struktur modal dari sebuah perusahaan yang dapat mempengaruhi pengeluaran atas biaya laporan pertanggung jawaban sosial perusahaan. Mengacu pada Jensen (1986) dan Zweibel (1996), menyatakan bahwa saat perusahaan mempunyai utang bunga yang tinggi, kemampuan manajemen berinvestasi lebih pada program Laporan pertanggung jawaban sosial perusahaan (CSR) adalah terbatas. Diamond (1991) dan Gilson (1990) menyatakan bahwa tingginya tingkat suku bunga utang juga mendorong kreditur untuk berperan aktif untuk mengawasi perusahaan (manajemen). Hasil penelitian mereka mendukung hipotesis bahwa Leverage yang lebih tinggi mempunyai hubungan negatif terhadap Laporan pertanggung jawaban sosial perusahaan.

\section{Efisiensi Biaya}

BOPO merupakan rasio antara biaya operasi terhadap pendapatan operasi. Biaya operasi merupakan biaya yang dikeluarkan oleh bank dalam rangka menjalankan aktivitas usaha utamanya seperti biaya bunga, biaya pemasaran, biaya tenaga kerja, dan biaya operasi lainnya. Pendapatan operasi merupakan pendapatan utama bank yaitu pendapatan yang diperoleh dari penempatan dana dalam bentuk kredit dan pendapatan operasi lainnya. Semakin kecil BOPO menunjukkan semakin efisien bank dalam menjalankan aktivitas usahanya. Bank yang sehat rasio BOPO-nya kurang dari satu sebaliknya bank yang kurang sehat, rasio BOPO-nya lebih dari satu. Menurut ketentuan Bank Indonesia efisiensi operasi diukur dengan BOPO.

Rasio biaya operasional digunakan untuk mengukur tingkat efisiensi dan kemampuan bank dalam melakukan kegiatan operasi (Dendawijaya, 2009). Semakin rendah BOPO berarti semakin efisien bank tersebut dalam mengendalikan biaya operasionalnya, dengan adanya efisiensi biaya maka keuntungan yang diperoleh bank akan semakin besar. Semakin kecil rasio beban operasionalnya akan lebih baik, karena bank yang bersangkutan dapat menutup beban operasional dengan pendapatan operasionalnya.

\section{Umur Perusahaan}

Umur perusahaan dapat mencerminkan seberapa besar perusahaan tersebut. Seberapa besar suatu perusahaan dapat digambarkan dalam kedewasaan perusahaan. Kedewasaan perusahaan akan membuat perusahaan yang bersangkutan memahami apa yang diinginkan oleh stakeholder dan shareholder nya. Perusahaan yang sudah lama berdiri tentunya akan mendapat perhatian lebih dari masyarakat luas. Dengan demikian, tentunya perusahaan yang sudah lama berdiri akan selalu menjaga stabilitas dan citra perusahaan. Untuk menjaga stabilitas dan citra, perusahaan akan berusaha mempertahankan dan meningkatkan kinerjanya.

Pengukuran umur perusahaan dihitung sejak berdirinya perusahaan sampai dengan data observasi (annual report) dibuat (latifah et al, 2011). Dari annual report yang diterbitkan perusahaan akan mengungkapkan seberapa bagus kemampuan perusahaan dalam menjaga stabilitas dan citra.

\section{Pengembangan Hipotesis}

Penelitian ini didasarkan pada teori yang meyatakan bahwa kinerja perusahaan yang baik akan diungkapkan oleh perusahaan dalam pelaporannya. Salah satu cara untuk menilai pelaporan tanggung jawab sosial perusahaan secara syariah yaitu dengan menggunakan indeks Islamic Social Reporting (ISR). Haniffa (2002), ISR adalah perpanjangan pelaporan sosial yang meliputi tidak hanya harapan dewan 
pengurus atas pandangan masyarakat terhadap peran perasaan dalam ekonomi tetapi juga pemenuhan perspektif spiritual untuk pengguna laporan muslim. Islamic Social Reporting memiliki dua tujuan utama, yang pertama sebagai akuntabilitas kepada Allah SWT dan komunitas dan yang kedua yaitu untuk meningkatkan transparansi kegiatan bisnis dengan cara memberikan informasi yang relevan dan sesuai dengan kebutuhan spiritual para pembuat keputusan muslim. Selain itu indeks ISR juga menekankan pada keadilan sosial terkait pelaporan mengenai lingkungan, kepentingan minoritas dan karyawan.

Perusahaan cenderung akan memberikan pengungkapan pelaporannya lebih banyak jika kinerja keuangan perusahaan semakin baik. Ukuran Kinerja dalam penelitian ini diwakili oleh Ukuran Perusahaan, Profitabilitas, Leverage dan BOPO Perbankan Syariah. Disamping kinerja Perusahaan, tingkat kedewasaan perusahaan juga dianggap mempengaruhi perusahaan dalam mengungkapkan pelaporannya. Semakin dewasa perusahaan maka akan semakin terbuka dalam mengungkapkan pelaporannya. Oleh karena itu maka dalam penelitian ini dirumuskan hipotesis sebagai berikut:

H1 : Ukuran Perusahaan berpengaruh positif terhadap pengungkapan Islamic Social Reporting (ISR) pada perbankan syariah di Indonesia

H2 : Profitabilitas berpengaruh positif terhadap pengungkapan Islamic Social Reporting (ISR) pada perbankan syariah di Indonesia

H3 : Leverage berpengaruh negatif terhadap pengungkapan Islamic Social Reporting (ISR) pada perbankan syariah di Indonesia

H4 : BOPO berpengaruh positif terhadap pengungkapan Islamic Social Reporting (ISR) pada perbankan syariah di Indonesia

H5 : Umur perusahaan berpengaruh positif terhadap pengungkapan Islamic Social Reporting (ISR) pada perbankan syariah di Indonesi

H6 : Ukuran, Profitabilitas, Likuiditas, BOPO dan Umur perusahaan berpengaruh positif terhadap pengungkapan Islamic Social Reporting (ISR) pada perbankan syariah di Indonesia

Kerangka pemikiran teoritis ini akan pengaruh Kinerja Keuangan (Size, ROA, DER, dan BOPO) dan Umur Perusahaan sebagai variabel independent, dan Islamic Social Reporting (ISR) sebagai variabel dependent.

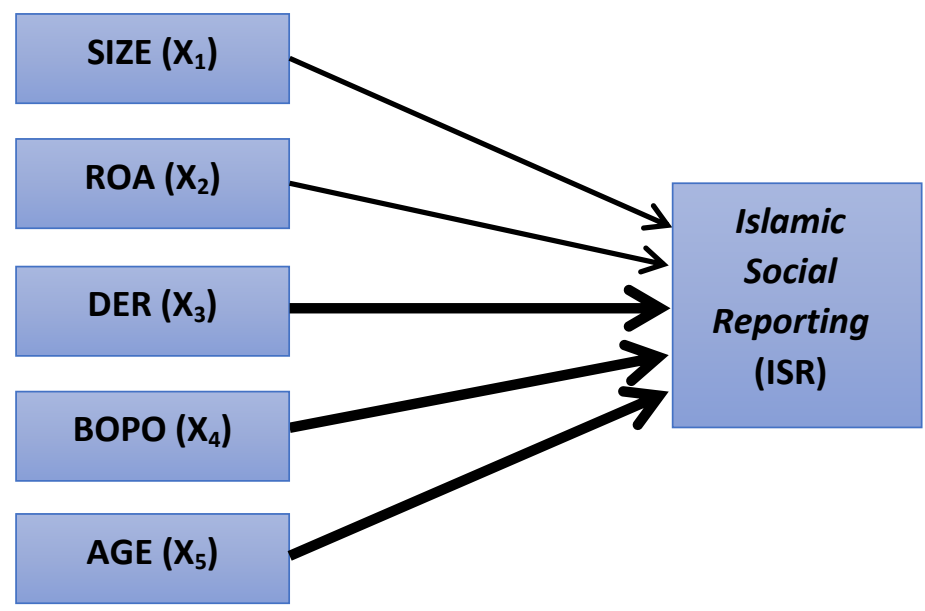




\subsection{Metode Penelitian}

Jenis yang digunakan dalam penelitian ini adalah data sekunder. Data sekunder dalam penelitian ini menggunakan data laporan tahunan perusahaan (annual report) yang dipublikasikan oleh masing masing bank syariah baik melalui web resminya maupun dipublikasi melalui BI tahun 2011-2016.

Penelitian ini menggunakan populasi target dalam menentukan populasi. Populasi dalam penelitian ini adalah seluruh perusahaan perbankan syariah di Indonesia yang berjumlah 12 unit bank. Metode pengambilan sampel dalam penelitian ini menggunakan jenis purposive sampling. Sampel yang digunakan dalam penelitian ini adalah perusahaan perbankan syariah yang memiliki kriteria tertentu. Teknik pengambilan sampel yang digunakan dalam penelitian ini yaitu purposive sampling, kriteria yang digunakan adalah:

a. Perusahaan perbankan syariah dan mempublikasikan annual report tahun 2011-2016 secara berturut-turut

b. Perusahaan perbankan syariah yang mengungkapkan Islamic Social Reporting dalam annual reportnya

c. Memiliki data lengkap yang berkaitan dengan variabel-variabel independen yang akan diteliti (Ukuran Perusahaan, Profitabilitas, Leverage, Efisiensi Biaya, dan Umur Perusahaan).

Metode pengumpulan data dalam penelitian ini adalah dengan menggunakan metode Dokumentasi.

\section{Islamic Social Reporting, (Y)}

ISR adalah variabel dependen yang diukur dengan indeks ISR dari masingmasing perusahaan setiap tahun. ISR dalam penelitian ini di ukur dengan menggunakan Nilai (score) dari indeks ISR dengan rumus.

Disclosure Level $=\frac{\text { jumlah skor disclosure yang dipenuhi }}{\text { jumlah skor maksimum }}$

\section{Ukuran Perusahaan (X1)}

Dalam penelitian ini Total aktiva dalam Milyaran atu Trilyunan Rupiah, sehingga perlu disederhanakan untuk mendapatkan data yang lebih rendah untuk dihitung sehingga menggunakn Ln Total Aktiva.

\section{Profitabilitas (X2)}

Profitabilitas adalah kemampuan suatu perusahaan untuk memperoleh keuntungan. Profitabilitas dalam penelitian ini diukur dengan menggunakan ROA (Return On Asset). ROA adalah perbandingan antara laba bersih setelah pajak dengan total Asset.

$$
\text { ROA }=\frac{\text { Laba setelah pajak }}{\text { Asset }}
$$

\section{Leverages (X3)}

Ratio Leverage yaitu ratio untuk mengukur sampai seberapa jauh aktiva perusahaan dibiayai dari hutang. Rasio Leverage atau Debt Ratio dapat diukur dengan menggunakan DER (Debt to Equity Ratio):

$$
D E R=\frac{\text { Total Debt }}{\text { Total Equity }} \times 100 \%
$$




\section{Efisiensi Biaya (X4)}

Efisiensi Biaya diukur dengan menggunakan rasio BOPO. BOPO merupakan rasio antara biaya operasi terhadap pendapatan operasi. Rasio BOPO adalah perbandingan antara biaya operasional dengan pendapatan operasional dalam mengukur tingkat efisiensi dan kemampuan bank dalam melakukan kegiatan operasinya. Rasio ini dirumuskan dengan:

$$
B O P O=\frac{\text { Beban Operasional }}{\text { Pendapatan operasional }} \times 100 \%
$$

\section{Umur Perusahaan (X5)}

Umur perusahaan dapat mencerminkan seberapa besar perusahaan tersebut. Seberapa besar suatu perusahaan dapat digambarkan dalam kedewasaan perusahaan. Perusahaan yang sudah lama berdiri tentunya akan mendapat perhatian lebih dari masyarakat sehingga akan selalu menjaga stabilitas dan citra perusahaan dengan mempertahankan dan meningkatkan kinerjanya. Pengukuran umur perusahaan dihitung sejak berdirinya perusahaan sampai dengan data observasi (annual report) dibuat.

Analisis data menggunakan model regresi linier berganda yang digunakan untuk melihat hubungan antara beberapa variabel independen dengan variabel dependen yang dilakukan dengan menggunakan Software SPSS.

Dalam penelitian ini pengujian dilakukan dengan menggunakan analisis regresi linier berganda, sehingga perlu dilakukan beberapa pengujian asumsi klasik yang bertujuan agar variabel independent atas variabel dependent tidak bias. Uji asumsi klasik diantaranya: Uji Normalitas, Uji Multikolinieritas, Uji Heteroskedastisitas, dan Uji Autokorelasi. Disamping itu juga dilakukan Analisis Deskriptif untuk menggambarkan "apa adanya" tentang sesuatu variabel, gejala atau keadaan.

\section{PEMBAHASAN}

\section{Deskripsi Objek Penelitian}

Analisis deskriptif ini mempunyai tujuan untuk memberikan gambaran atau deskripsi suatu obyek penelitian. Gambaran umum ini bisa menjadi acuan untuk melihat karakteristik data yang kita peroleh. Data dalam penelitian ini diperoleh dari data Laporan Keuangan dan Laporan Manajemen yang terdapat dalam Laporan Tahunan Bank Umum Syariah (BUS) di Indonesia yang di publikasikana. Data Annual Report dikumpulkan dan kemudian dianalisis untuk dihitung masing- masing variabelnya yaitu Kinerja Keuangan yang diwakili oleh Ukuran Perusanaan (Size), Return On Assets (ROA), DER, BOPO dan Umur Perusahaan dan ISR yang discoring dari 43 item ISR.

Data Laporan Tahunan Bank Umum Syariah (BUS) yang diperoleh sebanyak 69 Annual Report dari 12 Bank Umum Syariah (BUS) masing-masing diambil 6 tahun dari tahun 2011 sampai tahun 2016 dan hanya PT Bank Tabungan Pensiunan Nasional Syariah yang 3 Tahun Annual Report yaitu tahun 2014, 2015 dan 2016. 


\begin{tabular}{|l|r|r|r|r|r|r|}
\hline & \multicolumn{1}{|c|}{ Descriptive Statistics } \\
\hline SIZE & \multicolumn{1}{|c|}{ R } & \multicolumn{1}{c|}{ Range } & Minimum & Maximum & \multicolumn{1}{c|}{ Mean } & Std. Deviation \\
ROA & 69 & 78575948 & 255774 & 78831722 & 14820819.87 & 21214804.51 \\
DER & 69 & 29.11 & -20.13 & 8.98 & 9103 & 3.38240 \\
BOPO & 69 & 40.53 & -2.01 & 38.52 & 3.2051 & 6.07365 \\
AGE & 69 & 168.43 & 24.17 & 192.60 & 91.3697 & 27.48326 \\
ISR & 69 & 24.42 & .25 & 24.67 & 8.4203 & 6.25179 \\
Valid N (listwise) & 69 & 35.00 & 42.00 & 77.00 & 61.3623 & 9.28467 \\
\hline
\end{tabular}

Dari hasil analisis diskriptif yang bisa dilihat pada tabel diatas dapat diketahui bahwa untuk variabel Ukuran Perusahaan (SIZE) memiliki nilai minimum 255.774 (jutaan), nilai maksimum 78.831.722 (jutaan) memiliki rata-rata (mean) 14.820.819,87 (jutaan) dan standar deviasi Ukuran Perusahaan (SIZE) sebesar $14.820 .819,87$.

Variabel Profitabilitas (ROA) memiliki nilai minimum -20,13\%, nilai maksimum 8,98\%, memiliki rata-rata (mean) 0,91\% dengaan standar deviasi ROA sebesar 3,38.

Variabel Likuiditas Perusahaan (DER) memiliki nilai minimum -2,01\%, nilai maksimum 38,52\% memiliki rata-rata (mean) 3,21\% dan standar deviasi DER sebesar 6,07. Variabel Efisiensi Biaya Perusahaan (BOPO) memiliki nilai minimum 24,17\%, nilai maksimum 192,60\% memiliki rata-rata (mean) 91,37\% dan standar deviasi BOPO sebesar 27,46.

Variabel Umur Perusahaan (AGE) memiliki bank yang memiliki umur minimum 0,25 tahun yaitu pada Maybank Syariah Indonesia tahun 2011 dimana usia bank baru 3 bulan atau 0,25 tahun, umur maksimum 24,67 tahun yaitu pada bank muamalat Indonesia tahun 2016 sedangkan rata rata data menunjukkan bahwa umur rata-rata (mean) 8,42 tahun dan standar deviasi sebesar 6,25.

Variabel Islamic Social Reporting (ISR) memiliki nilai minimum 42\% pada BJB tahun 2015, nilai maksimum 77\% pada Bank Muamalat Indonesia Tahun 2012, memiliki rata-rata (mean) 61,36\% dan standar deviasi sebesar 9,28.

\section{Uji Kualitas Data}

Hasil analisis yang dapat dilihat pada grafik Histogram dan Normal P-Plot diketahui bahwa sebaran data yang menyebar ke semua daerah kurva normal. Dapat disimpulkan bahwa data mempunyai distribusi normal. Demikian juga dengan Normal P-Plot menunjukkan bahwa titik-titik menyebar disekitar garis diagonal sehingga dapat dikatakan bahwa penelitian ini memenuhi asumsi pola distribusi normal. Data yang menyebar di sekitar garis diagonal dan mengikuti garis diagonal yang menandakan normalitas data.

Dari hasil table coefficient dapat diketahui nilai variance inflation factor (VIF) masing-masing variabel yaitu In Size, ROA, DER, BOPO dan AGE lebih kecil dari 5, sehingga bisa diduga bahwa antar variabel independen tidak terjadi persoalan multikolinearitas. 


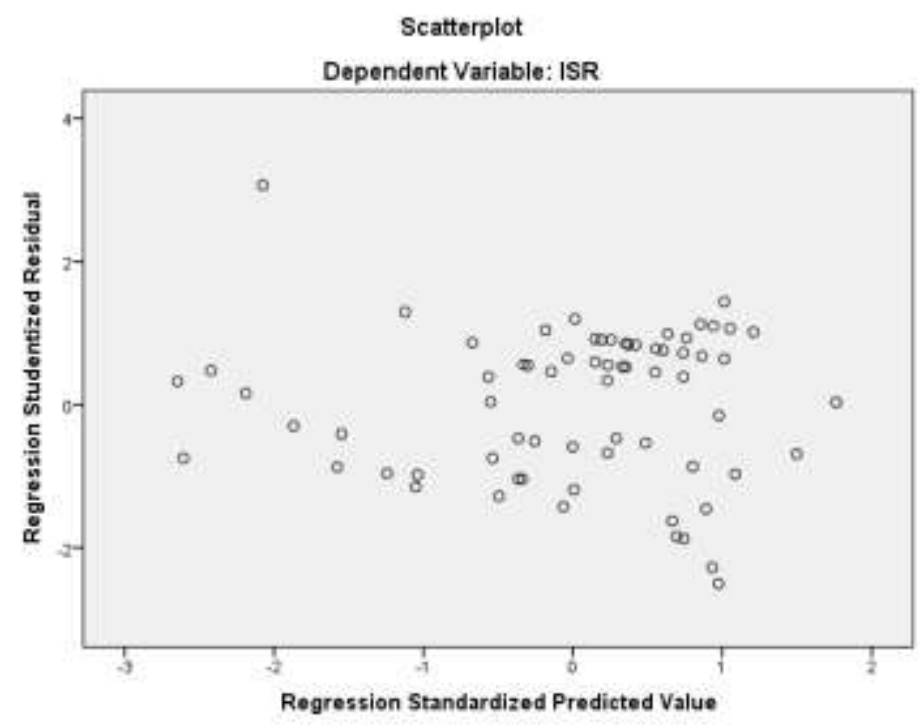

Sumber: Data diolah 2017

Uji heterokendastisitas dalam penelitian ini menggunakan uji scatterplot. Hasil analisis pada gambar scatterplot diatas menunjukkan bahwa tidak ada pola yang jelas, seperti titik-titik menyebar di atas dan di bawah angka 0 pada sumbu Y, sehingga dapat disimpulkan bahwa tidak terjadi heteroskedastisitas.

Dari hasil output Model Summary didapat nilai DW yang dihasilkan dari model regresi adalah 0,335. Sedangkan dari tabel DW dengan signifikansi 0,05 dan jumlah data $(\mathrm{n})=69$, serta $\mathrm{k}=5$ ( $\mathrm{k}$ adalah jumlah variabel independen) diperoleh nilai $\mathrm{dL}$ sebesar 1,4588 dan dU sebesar 1,7680 (lihat lampiran). Karena nilai DW $(0,335)$ berada pada daerah antara 0 dan $\mathrm{dL}(0<\mathrm{DW}<\mathrm{dL})$, maka dapat dikatakan tidak ada autokorelasi positif.

\section{Pengujian Hipotesis}

Untuk menguji Hipotesis 1 sampai dengan hipotesis 5, maka dilakukan analisis regresi berganda. Pengujian hipotesis dengan menggunakan SPSS menunjukkan hasil analisis sebagai berikut:

Tabel 1

Model Summary

Model Summaryb

\begin{tabular}{|c|c|c|c|c|c|}
\hline Model & $\mathrm{R}$ & $\begin{array}{r}\mathrm{R} \\
\text { Square }\end{array}$ & $\begin{array}{r}\text { Adjust } \\
\text { ed R Square }\end{array}$ & $\begin{array}{r}\text { Std. Error } \\
\text { of the Estimate }\end{array}$ & $\begin{array}{r}\text { Durbi } \\
\text { n-Watson }\end{array}$ \\
\hline 1 & \begin{tabular}{|ll} 
& .3 \\
$29 a$ &
\end{tabular} & $\begin{array}{ll} & .1 \\
09 & \end{array}$ & .038 & 9.10750 & .335 \\
\hline
\end{tabular}

a. Predictors: (Constant), AGE, ROA, DER, BOPO, In_SIZE

b. Dependent Variable: ISR 
Tabel 2

ANOVA

ANOVA $^{\mathrm{a}}$

\begin{tabular}{|c|c|c|c|c|c|}
\hline Model & $\begin{array}{l}\text { Sum of } \\
\text { Squares }\end{array}$ & f & $\begin{array}{l}\text { Mean } \\
\text { Square }\end{array}$ & & Fig. \\
\hline \multirow{3}{*}{\begin{tabular}{cc} 
& \multicolumn{2}{c}{ Regr } \\
ession & \\
& Resid \\
ual & \\
& Total
\end{tabular}} & 636.308 & & 127.26 & .534 & $192^{\mathrm{b}}$ \\
\hline & 5225.634 & 3 & 82.947 & & \\
\hline & 5861.942 & 8 & & & \\
\hline
\end{tabular}

a. Dependent Variable: ISR

b. Predictors: (Constant), AGE, ROA, DER, BOPO, In_SIZE

Sumber: Data diolah, 2017

Tabel 3

Coefficients

Coefficients ${ }^{a}$

\begin{tabular}{|c|c|c|c|c|c|c|c|}
\hline \multirow[b]{2}{*}{ Model } & \multicolumn{2}{|c|}{$\begin{array}{l}\text { Unstandardiz } \\
\text { ed Coefficients }\end{array}$} & \multirow{2}{*}{$\begin{array}{c}\begin{array}{c}\text { Standardiz } \\
\text { ed Coefficients }\end{array} \\
\text { Beta }\end{array}$} & & \multirow[b]{2}{*}{ ig. } & \multicolumn{2}{|c|}{$\begin{array}{l}\text { Collinearity } \\
\text { Statistics }\end{array}$} \\
\hline & B & $\begin{array}{l}\text { Std. } \\
\text { Error }\end{array}$ & & & & ance $^{\text {Toler }}$ & IF \\
\hline $\begin{array}{l}\text { (Con } \\
\text { stant) }\end{array}$ & $.079^{82}$ & $466^{15.7}$ & & $.213^{5}$ & 000 & & \\
\hline $\mathrm{ZE} \quad{ }^{\ln \_\mathrm{SI}}$ & $1.493^{-}$ & $1 \quad 1.08$ & -.280 & $1.381^{-}$ & 172 & .345 & $.898^{2}$ \\
\hline ROA & $67^{.0}$ & .503 & .025 & 134 & 894 & .422 & $.370^{2}$ \\
\hline DER & $.333^{-}$ & .201 & -.218 & $1.658^{-}$ & 102 & .819 & $.221^{1}$ \\
\hline BOP & $.033^{-}$ & .061 & -.098 & $.538^{-}$ & 592 & .430 & $.324^{2}$ \\
\hline AGE & $27^{.7}$ & .302 & .489 & $.403^{2}$ & 019 & .341 & $.930^{2}$ \\
\hline
\end{tabular}

a. Dependent Variable: ISR

Sumber: Data diolah, 2017

Hasil analisis persamaan Tabel Coefficient diatas menunjukkan bahwa Ln_SIZE, ROA, DER dan BOPO tidak signifikan berpengaruh terhadap ISR. Signifikansi ln_SIZE terhadap ISR sebesar 0,172>0,05, Signifikansi ROA terhadap ISR sebesar 0,894>0,05 Signifikansi DER terhadap ISR sebesar 0,102> 0,05 dan Signifikansi BOPO terhadap ISR sebesar 0,592>0,05. Sedangkan signifikansi AGE terhadap ISR sebesar 0,019< 0,05 menunjukkan bahwa AGE signifikan berpengaruh terhadap ISR. 


\section{Pengaruh SIZE Terhadap ISR}

Hipotesis yang diajukan dalam penelitian ini adalah Ukuran Perusahaan berpengaruh positif terhadap pengungkapan Islamic Social Reporting (ISR) pada perbankan syariah di Indonesia. Dari hasil Hasil analisis dengan menggunakan program SPSS pada Tabel 13 Coefficient diatas menunjukkan nilai Unstandardised beta Ln_SIZE -0,280 dengan signifikansi dihasilkan yaitu sebesar 0,172 > 0,005. Maka dapat dikatakan bahwa ukuran bank (Ln_SIZE) memiliki kooefisien beta negative terhadap ISR dan terbukti tidak signifikan berpengaruh terhadap ISR.

Persamaan diatas menunjukkan bahwa koefisien regresi ukuran perusahaan sebesar $-0,280$. Nilai tersebut berarti bahwa setiap peningkatan ukuran perusahaan sebesar satu poin, maka pengungkapan ISR akan turun sebesar 0,260 poin. Tanda negative pada koefisien regresi dan nilai signifikansi sebesar 0,172 lebih besar dari dari taraf signifikansi yang telah ditetapkan yaitu 0,05 menunjukkan bahwa SIZE berpengaruh negative dan tidak signifikan terhadap ISR pada Perbankan Syariah di Indonesia.

Hasil analisis ini berbeda dengan penelitian Aldehita (2014), Kariza (2013), Lestari (2014), Raditya (2012), Yuyetta (2012), dan widiawati (2012) yang menunjukkan hasil bahwa Ukuran Perusahaan mempunyai arah pengaruh yang positif terhadap ISR, walaupun hasil penelitian Aldehita (2014) menunjukan hasil yang tidak signifikan. Berdasarkan hasil uji hipotesis penelitian ini dapat dikatakan bahwa hipotesis pertama yang berbunyi "Ukuran Perusahaan berpengaruh positif terhadap pengungkapan Islamic Social Reporting (ISR) pada perbankan syariah di Indonesia" ditolak. Dengan demikian dapat disimpulkan bahwa variabel ukuran perusahaan berpengaruh negatif dan tidak signifikan terhadap pengungkapan pengungkapan Islamic Social Reporting (ISR) pada perbankan syariah di Indonesia.

\section{Pengaruh ROA Terhadap ISR}

Regresi Linear Berganda digunakan untuk menguji ada tidaknya pengaruh variabel independen yaitu Ukuran Perusahaan (Ln_SIZE), Return on Asset (ROA), Debt to Equity Ratio (DER), BOPO, dan Umur Perusahaan (AGE) secara simultan terhadap variabel dependen yaitu Pengungkapan ISR. Hasil analisis Standardised beta ROA menunjukkan nilai Unstandardized Coefficient sebesar 0,067 dengan signifikansi yang dihasilkan yaitu sebesar 0,894 > 0,005. Maka dapat dikatakan bahwa Kinerja Keuangan (ROA) terbukti tidak signifikan berpengaruh terhadap ISR. Koefisien regresi ukuran perusahaan sebesar 0,067. Nilai tersebut berarti bahwa setiap peningkatan ROA perusahaan sebesar satu poin, maka pengungkapan ISR akan naik sebesar 0,067 poin. Tanda positif pada koefisien regresi dan nilai signifikansi sebesar 0,894 lebih besar dari dari taraf signifikansi yang telah ditetapkan yaitu 0,05 menunjukkan bahwa ROA berpengaruh positif dan tidak signifikan terhadap ISR pada Perbankan Syariah di Indonesia.

Hasil ini sesuai dengan penelitian Ari (2016) sebelumnya yang menyatakan hasil bahwa ROA tidak terbukti signifikan berpengaruh terhadap ISR. Penelitian Barnas dkk (2016) juga menunjukkan bahwa Profitabilitas tidak berpengaruh terhadap Corporate Social Responsibility (CSR)ii dimana ISR adalah bagian dari pengembangan Corporate Social Responsibility (CSR). Penelitian Aldehita (2014), Kariza (2013), Lestari (2014), Raditya (2012), Yuyetta (2012), dan widiawati (2012) yang menunjukkan hasil bahwa Ukuran Perusahaan mempunyai arah pengaruh yang positif terhadap ISR, walaupun hasil penelitian Lestari (2014) menunjukan hasil yang tidak signifikan sama dengan hasil pada penelitian ini. 
Berdasarkan hasil uji hipotesis penelitian ini dapat dikatakan bahwa hipotesis kedua yang berbunyi "Profitabilitas berpengaruh positif terhadap pengungkapan Islamic Social Reporting (ISR) pada perbankan syariah di Indonesia" ditolak. Dengan demikian dapat disimpulkan bahwa variabel Profitabilitas perusahaan arah pengaruh positif namun tidak signifikan terhadap pengungkapan Islamic Social Reporting (ISR) pada perbankan syariah di Indonesia.

Dari Tabel coefficients dapat diperoleh persamaan regresi sebagai berikut:

ISR $=82,079-1,493$ Ln_SIZE + 0,067 ROA - 0,333 DER - 0,033 BOPO + 0,727

Hasil analisis statistik pada Tabel 12. ANOVA diatas menunjukkan bahwa signifikansi uji $\mathrm{F}$ lebih dari $5 \%$ yaitu 0,192 sehingga secara simultan SIZE, ROA, DER,BOPO dan AGE juga tidak terbukti signifikan berpengaruh terhadap ISR.

Hasil analisis pada Tabel Model Summary diatas menunjukkan hasil $R$-Square untuk ISR sebesar 0,109 yang memiliki arti bahwa pengaruh variabel SIZE, ROA, DER,BOPO dan AGE terhadap ISR adalah sebesar 10,9\% dan sisanya sebesar 89,1\% dipengaruhi oleh variabel lain diluar model penelitian ini. $R$ - Square yang relatif sangat kecil ini membuktikan bahwa lebih banyak variabel diluar penelitian SIZE, ROA, DER, BOPO dan AGE yang berpengaruh terhadap pengungkapan ISR.

\section{Pengaruh DER Terhadap ISR}

Analisis pengaruh Leverage terhadap ISR menggunakan DER. Hasil analisis Standardised beta DER menunjukkan nilai sebesar -0,333 dengan signifikansi yang dihasilkan yaitu sebesar 0,102 >0,005. Unstandardised Beta DER menunjukkan nilai negative menunjukkan bahwa setiap peningkatan DER akan menurunkan ISR sebesar $-0,333$. Sedangkan signifikansi 0,102 > 0,005 dapat dikatakan bahwa DER terbukti tidak signifikan berpengaruh terhadap ISR. Signifikansi DER terhadap ISR sebesar 0,102 > 0,05 Dengan demikian dapat disimpulkan bahwa variabel leverage berpengaruh negatif dan tidak signifikan terhadap pengungkapan ISR Bank Syariah yang diukur dengan DER (Debt to Equity Ratio).

Penelitian Lestari (2014) dan Dewi (2012) yang menunjukkan hasil bahwa Leverage yang menunjukkan rasio Utang Perusahaan mempunyai arah pengaruh yang positif terhadap ISR, walaupun hasil penelitian Dewi (2012) menunjukan hasil yang signifikan. Kedua penelitian tidak mendukung hasil dari penelitian ini.

Berdasarkan hasil uji hipotesis penelitian ini dapat dikatakan bahwa hipotesis ketiga yang berbunyi "Leverage berpengaruh negatif terhadap pengungkapan Islamic Social Reporting (ISR) pada perbankan syariah di Indonesia" ditolak. Dengan demikian dapat disimpulkan bahwa variabel Leverage perusahaan memiliki arah pengaruh negative namun tidak signifikan terhadap pengungkapan Islamic Social Reporting (ISR) pada perbankan syariah di Indonesia.

\section{Pengaruh BOPO Terhadap ISR}

Hasil analisis Unstandardised beta BOPO menunjukkan nilai sebesar -0,033 dengan signifikansi yang dihasilkan yaitu sebesar 0,592 > 0,005. Maka dapat dikatakan bahwa Kinerja Keuangan (BOPO) terbukti tidak signifikan berpengaruh terhadap ISR. dan Signifikansi BOPO terhadap ISR sebesar 0,592> 0,05. Unstandardised Beta DER menunjukkan nilai negative menunjukkan bahwa setiap 
peningkatan DER akan menurunkan ISR sebesar -0,033. Sedangkan signifikansi 0,592 $>0,005$ dapat dikatakan bahwa BOPO terbukti tidak signifikan berpengaruh terhadap ISR. Dengan demikian dapat disimpulkan bahwa variabel BOPO berpengaruh negatif dan tidak signifikan terhadap pengungkapan ISR Bank.

Berdasarkan hasil uji hipotesis penelitian ini dapat dikatakan bahwa hipotesis keempat yang berbunyi "BOPO berpengaruh positif terhadap pengungkapan Islamic Social Reporting (ISR) pada perbankan syariah di Indonesia" ditolak. Dengan demikian dapat disimpulkan bahwa variabel BOPO perusahaan memiliki arah pengaruh negative dan tidak signifikan berpengaruh terhadap pengungkapan Islamic Social Reporting (ISR) pada perbankan syariah di Indonesia.

\section{Pengaruh AGE Terhadap ISR}

Hasil analisis Unstandardised beta Umur Perusahaan (AGE) menunjukkan nilai sebesar 0,727. Sedangkan signifikansi AGE terhadap ISR sebesar 0,019<0,05 menunjukkan bahwa AGE signifikan berpengaruh terhadap ISR. Koefisien regresi ukuran perusahaan sebesar 0,727 berarti bahwa setiap peningkatan Umur perusahaan sebesar satu poin, maka pengungkapan ISR akan naik sebesar 0,727 poin. Tanda positif pada koefisien regresi dan nilai signifikansi sebesar 0,019 kurang dari taraf signifikansi yang telah ditetapkan yaitu 0,05 menunjukkan bahwa AGE berpengaruh positif dan signifikan terhadap pengungkapan ISR pada Perbankan Syariah di Indonesia.

Hasil penelitian ini juga didukung oleh penelitian sebelumnya yaitu penelitian Raditya (2012) yang menyatakan bahwa Umur Perusahaan mempunyai arah pengaruh yang positif dan signifikan terhadap pengungkapan ISR pada perusahaan yang masuk Daftar Efek Syariah (DES).

Berdasarkan hasil uji hipotesis penelitian ini dapat dikatakan bahwa hipotesis kelima yang berbunyi "Umur perusahaan berpengaruh positif terhadap pengungkapan Islamic Social Reporting (ISR) pada perbankan syariah di Indonesia" diterima.

Dari kelima independent variable tersebut hanya Umur Perusahaan (AGE) yang terbukti signifikan berpengaruh terhadap ISR. Hal ini menunjukkan bahwa ISR tidak semata mata dipengaruhi oleh faktor keuangan saja, tapi lebih dipengaruhi oleh faktor di luar keuangan. Umur perusahaan menunjukkan tingkat kedewasaan dan kematangan perusahaan sehingga dengan umur yang semakin dewasa perusahaan akan lebih bertanggungjawab kepada stockholdernya.

\section{Pengaruh SIZE, ROA, DER, BOPO dan AGE Secara Simultan Terhadap ISR}

Hasil analisis persamaan Tabel Coefficient diatas menunjukkan bahwa Ln_SIZE, ROA, DER dan BOPO tidak signifikan berpengaruh terhadap ISR. Signifikansi ln_SIZE terhadap ISR sebesar 0,172>0,05, Signifikansi ROA terhadap ISR sebesar 0,894>0,05 Signifikansi DER terhadap ISR sebesar 0,102> 0,05 dan Signifikansi BOPO terhadap ISR sebesar 0,592>0,05. Sedangkan signifikansi AGE terhadap ISR sebesar 0,019< 0,05 menunjukkan bahwa AGE signifikan berpengaruh terhadap ISR.

Hasil analisis statistik pada Tabel ANOVA menunjukkan bahwa signifikansi uji $\mathrm{F}$ lebih dari 5\% yaitu 0,192 sehingga secara simultan SIZE, ROA, DER,BOPO dan AGE tidak terbukti signifikan berpengaruh terhadap ISR. Sedangkan hasil analisis pada Tabel Model Summary menunjukkan hasil $R$ - Square untuk ISR sebesar 0,109 yang memiliki arti bahwa pengaruh variabel independent yaitu SIZE, ROA, DER,BOPO dan 
AGE terhadap variable dependent yaitu pengungkapan ISR adalah sebesar $10,9 \%$ dan sisanya sebesar $89,1 \%$ dipengaruhi oleh variabel lain diluar model penelitian ini. $R-$ Square yang relatif sangat kecil ini membuktikan bahwa lebih banyak variabel diluar penelitian SIZE, ROA, DER, BOPO dan AGE yang berpengaruh terhadap pengungkapan ISR.

Berdasarkan hasil uji hipotesis penelitian ini dapat dikatakan bahwa hipotesis keenam yang berbunyi "Ukuran, Profitabilitas, Likuiditas, BOPO dan Umur perusahaan berpengaruh positif terhadap pengungkapan Islamic Social Reporting (ISR) pada perbankan syariah di Indonesia" ditolak. Dengan demikian dapat disimpulkan bahwa secara simultan variabel SIZE, ROA, DER, BOPO dan AGE perusahaan secara simultan terbukti tidak signifikan berpengaruh terhadap pengungkapan Islamic Social Reporting (ISR) pada perbankan syariah di Indonesia.

\section{PENUTUP}

Hasil analisis statistik pada penelitian ini dapat disimpulkan bahwa:

1. Ukuran Perusahaan (Size) terbukti tidak signifikan berpengaruh berpengaruh terhadap pengungkapan Islamic Social Reporting (ISR) pada perbankan syariah di Indonesia

2. Profitabilitas Perusahaan (ROA) tidak signifikan berpengaruh terhadap pengungkapan Islamic Social Reporting (ISR) pada perbankan syariah di Indonesia.

3. Likuiditas Perusahaan (DER) tidak signifikan berpengaruh terhadap pengungkapan Islamic Social Reporting (ISR) pada perbankan syariah di Indonesia

4. Efisiensi Biaya Perusahaan (BOPO) tidak signifikan berpengaruh terhadap pengungkapan Islamic Social Reporting (ISR) pada perbankan syariah di Indonesia

5. Umur $(A G E)$ Perusahaan berpengaruh signifikan terhadap pengungkapan Islamic Social Reporting (ISR) pada perbankan syariah di Indonesia

6. Secara simultan Ukuran, Profitabilitas, Likuiditas, Efisiensi Biaya dan Umur Perusahaan tidak signifikan berpengaruh terhadap pengungkapan Islamic Social Reporting (ISR) pada perbankan syariah di Indonesia.

Hasil tersebut menunjukkan bahwa ISR tidak dipengaruhi oleh semata-mata faktor keuangan perusahaan, namun faktor lain selain faktor keuangan lebih mempengaruhi pengungkapan ISR pada perbankan syariah misalnya faktor kedewasaan perusahaan yang diukur dengan Umur Perusahaan. 


\section{REFERENSI}

Anggraini, Vivi. (2015) Pengaruh Pengungkapan Islamic Social Reporting (ISR), Profitabilitas, dan Leverage Terhadap Earning Response Coefficient (ERC) (Studi Empiris pada Perusahaan yang Terdaftar di Jakarta Islamic Index Tahun 20102013). Jakarta: UIN Syarif Hidayatullah

Astuti, Tri Puji. (2014) Faktor-Faktor yang Mempengaruhi Pengungkapan Islamic Social Reporting (ISR) pada Bank Syariah di Indonesia. Eprints.ums.ac.id/29266/17/NASKAH_PUBLIKASI.pdf.

Astuti, Tri Puji.(2014) Faktor - Faktor Yang Mempengaruhi Pengungkapan Islamic Social Reporting (ISR) Pada Bank Syariah Di Indonesia. Surakarta: Universitas Muhammadiyah Surakarta.

Arikunto, Suharsimi.( 2013). Manajemen Penelitian. Jakarta: PT Rieneka Cipta

Azheri, Busyra. (2006). Corporate Social Responsibility. Jakarta: Rajawali Pers.

Barnas. Alyssa Natasya; Hapsari, Dini Wahjoe; Yudowati, Siska Priyandani. Pengaruh Profitabilitas Dan Ukuran Perusahaan Terhadap Pengungkapan Corporate Social Responsibility (Studi Empiris pada Perusahaan Subsektor Makanan dan Minuman yang Terdaftar di Bursa Efek Indonesia tahun 2011-2014), eProceeding of Management : Vol.3, No.2 Agustus 2016 | Page 1566

Bungin, Burhan. (2015). Metodologi Penelitian Kuantitatif Komunikasi, Ekonomi, dan Kebijakan Publik Serta Ilmu-ilmu Sosial Lainya. EDISI KEDUA. Jakarta: Kencana.

Darmawan, Deni. (2013). Metodologi Penelitian Kuantitatif. Bandung: PT Rosdakarya Offset.

Dewi, Indah Fitri Karunia. (2012). Analisis Pengaruh Profitabilitas, Leverage, Ukuran Perusahaan, dan Porsi Kepemilikan Publik Atas Saham Terhadap Pengungkapan Islamic Social Reporting Pada Perusahaan Jakarta Islamic Index. Depok: Universitas Indonesia.

Fadlillah, R. N. (2014). Pengaruh Karakteristik Perusahaan Terhadap Pengungkapan Corporate Social Responsibility . jurnal Ilmu \& Riset Akuntansi Vol.3, 1-15.

Ghozali, I. (2013). Aplikasi Analisis Multivariate dengan Program IBM SPSS 21. Semarang: Badan Penerbit Universitas Diponegoro.

Harian Neraca. "Saham Syariah Ungguli IHSG dan LQ45" Artikel diakses pada 8 Februari 2015 dari http://www.neraca.co.id/bursa-saham/35793/SahamSayriah-Ungguli-IHSG-dan-LQ45

Kasmir. Analisis Laporan Keuangan. Jakarta: Rajawali Pers. 2009

Maulida, Aldehita Purnasantri et, al., Analisis Faktor-Faktor yang Mempengaruhi Pengungkapan Islamic Social Reporting (ISR). Multiparadigma.lecture.ub.ac.id/files/2014/09/112.pdf. 2014

Munawir, (2012). S. Analisis Laporan Keuangan. Yogyakarta: Liberty.

Muslich, Mohamad. (2007). Manajemen Keuangan ModernAnalisis, Perencanaan, dan Kebijaksanaan, Jakarta: Bumi Aksara.

Martono, Nanang. (2012). Metode Penelitian Kuantitatif Analsis Isi dan Analisis Data Sekunder Edisi Revisi. Jakarta: PT RajaGrafindo Persada.

Ningrum, Ratna Aditya et.,al. Pengaruh Kinerja Keuangan Kepemilikan Institusional dan Ukuran Dewan Pengawas Syariah Terhadap ISR. http://journal.unnes.ac.id/sju/index.php/aaj. Semarang: 2013

Otoritas Jasa Keuangan. "Statistik Pasar Modal", data diakses pada tanggal 17 Februari 2015 dari http://www.ojk.go.id/dl.php?i=2183

Prasetya, Bambang \& Lina Miftahul Jannah. (2006). Metodologi Penelitian Kuantitatif. Jakarta: PT RajaGrafindo Persada. 
Raditya, Amilia Nurul. (2012). Analisis Faktor-Faktor Yang Mempengaruhi Tingkat Pengungkapan Islamic Social Reporting (ISR) Pada Perusahaan Yang Masuk Daftar Efek Syariah (DES). Depok: Universitas Indonesia.

Rahmawati. (2012). Teori Akuntansi Keuangan. Yogyakarta: Graha Ilmu.

Solihin, Ismail. (2012). Manajemen Strategik. Bandung: Erlangga.

Sunariyah. (2011). Edisi Keenam Pengantar Pengetahuan Pasar Modal. Yogyakarta: Unit Penerbit Dan Percetakan Sekolah Tinggi Ilmu Manajemen YKPN.

Sudarsono, Heri. (2012). Bank dan Lembaga Keuangan SYARIAH. Yogyakarta: Ekonisia.

Sule, Ernie Tisnawati \& Kurniawan Saefullah.( 2005). Pengantar Manajemen. Jakarta: Kencana.

Sutrisno. (2000). Manajemen Keuangan Teori Konsep \& Aplikasi. Yogyakarta: Ekonisia.

Siregar, Syofian. (2013). Metode Penelitian Kuantitatif Dilengkapi Dengan Perhitungan Manual \& SPSS. Jakarta: Kencana Prenadamedia Group.

Sudana, I Made. (2011). Manajemen Keuangan Teori dan Praktik. Jakarta: Erlangga.

Sartono, Agus. (1990). Manajemen Keuangan Teori dan Aplikasi Edisi 1. Yogyakarta: BPFE.

Suharyadi \& Purwanta. (2009). Buku 2 Statistik Untuk Ekonomi dan Keuangan Modero. Jakarta: Salemba Empat.

Sarwono, Jonathan. (2012). Metode Riset Skripsi Pendekatan Kuantitatif Menggunakan Prosedur SPSS Tuntunan Praktis dalam Menyusun Skripsi. Jakarta: PT Elex Media Komputindo.

Uha, Ismail Nawawi. (2013). Budaya Organisasi Kepemimpinan Dan Kinerja. Jakara: Kencana Prenadamedia Group.

Widiawati, Septi dan Surya Raharja. "Analisis Faktor-faktor yang yang Mempengaruhi Islamic Social ReportingPerusahaan-perusahaan yang Terdapat pada Daftar Efek SyariahTahun 2009-2011". Diponegoro Journal Of Accounting. Semarang: 2012

Wild, John J .(2005). Financial Statement Analysis Analisis Laporan Keuangan.Jakarta: Salemba Empat. 